\title{
Rainfall Variability and Trend Analysis of Annual Rainfall in North Africa
}

\author{
Zeineddine Nouaceur ${ }^{1}$ and Ovidiu Murărescu ${ }^{2}$ \\ ${ }^{1}$ UMR CNRS 6228 IDEES, University of Rouen, Rouen, France \\ ${ }^{2}$ Department of Geography, "Valahia" University, Târgovişte, Romania \\ Correspondence should be addressed to Zeineddine Nouaceur; zeineddine.nouaceur@univ-rouen.fr
}

Received 7 June 2016; Revised 8 September 2016; Accepted 26 September 2016

Academic Editor: Prodromos Zanis

Copyright (C) 2016 Z. Nouaceur and O. Murărescu. This is an open access article distributed under the Creative Commons Attribution License, which permits unrestricted use, distribution, and reproduction in any medium, provided the original work is properly cited.

\begin{abstract}
The IPCC climate models predict, for the Maghreb countries, lower rainfall and increased aridity. Current observations in the three countries of central Maghreb (Morocco, Algeria, and Tunisia) are not consistent with these predictions. To demonstrate this new trend, a detailed regional analysis of rainfall evolution is conducted. This investigation is based on the calculation of the reduced centered index and the chronological graphical method of processing information (MGCTI) of "Bertin matrix" type. The results show extreme variability of this parameter and the severe past drought (more intense for Morocco, in which the drastic conditions from the seventies are observed). The results also show the beginning of a gradual return to wetter conditions since the early $2000 \mathrm{~s}$ in Algeria and Tunisia and from 2008 for Morocco (this trend is confirmed by recent agricultural production data in 2011/2012 and 2012/2013)
\end{abstract}

\section{Introduction}

Climate change is today acknowledged by a large part of the scientific community. In its latest report, the IPCC [1] in 2013 evaluates the average trend of world temperature over the period $1880-2012$ equal to $0.85^{\circ} \mathrm{C}$ with a degree of uncertainty ranging between $0.65^{\circ} \mathrm{C}$ and $1.06^{\circ} \mathrm{C}$. The rise that occurred during the last decade (2003-2012) is $+0.78^{\circ} \mathrm{C}$ (for a minimum of $0.72^{\circ} \mathrm{C}$ and a maximum of $0.85^{\circ} \mathrm{C}$ ). The National Climatic Data Center, NCDC, considers the year 2014 as the warmest ever recorded, with an anomaly of $+0.69^{\circ} \mathrm{C}$ (calculated for the period 1880-2014) [2]. The World Meteorological Organisation [3] considers the period 20112015 as the hottest on record, and the year 2015 as the hottest since modern observations began in the late 1800s. If, on a global scale, the increase in temperatures is unquestionable, the evolution of world pluviometry is much more contrasting as it is subject to a strong spatiotemporal variability. Despite this feature, and considering temperature rise, an increase in rainfall is likely to occur in certain region of the world favorable to such climate evolution. Indeed, the hydrological cycle acceleration under the influence of strong temperatures might lead to more rainfall and evaporation [4]. The results of several studies on rainfall evolution in many areas of the globe, as it happens in North Africa, show that climate change translates into wetter conditions $[5,6]$ as well as into a rainfall increase and repetition of extreme events (perceptible in the recent decades 1991-2010) [4, 7-9].

The Mediterranean area is known today as a "hot spot" of climate change [10-12]. This large inner sea stretching from the Strait of Gibraltar to the Lebanese coasts over an area of almost $4,000 \mathrm{~km}$ has a total surface of 2.51 million $\mathrm{km}$. On the whole, this area is characterised by a well-defined summer drought and, depending on the subregions, by a maximum precipitation in autumn or winter [13]. During summer, rainfall is scarce. In this season, the Azores anticyclone moves north. When the anticyclone retreats south, it leaves free the passage to the ocean disturbances affecting North Africa. The rainy season begins in the fall and continues to the spring. The Mediterranean climate is subtropical (Csa and Csb, according to Koppen classification); however, cyclone activity presents large seasonal and spatial variability, with large differences from western to eastern Mediterranean and between cold and warm seasons [14]. The importance of this 
water mass on a regional scale explains the vast expanse in space of the Mediterranean climate domain. According to the results of various prediction of climatic models, both global and regional, a rise in temperatures and decrease in rainfall are expected [15-17]. Thus, by 2100, these regions should experience an average rise in temperature of $3-4^{\circ} \mathrm{C}$, a decrease of rainfall, and increase of extreme events [12]. Philandras et al. [18] based on the future projections of regional climate model RACMO2/KNMI show that annual precipitation within the majority of Mediterranean is very likely to decrease on an average of 20\%, during the period 2071-2100 compared to 1961-1990, under scenario "SRES" “A1B." The works of Giannakopoulos et al. [19] lead to the same result with a $20 \%$ rainfall decline south of the Mediterranean Sea according to a climate warming scenario of $+2^{\circ} \mathrm{C}$. Tselioudis et al. [20], based on the results of first scenario, showed a marked decrease in winter precipitation value by the end of the 21st century. Dubrovský et al. [21] analyzed future climate conditions for the Mediterranean region based on 16 Global Climate Models. For temperature, the results show an increase for all parts of the Mediterranean. For precipitation, a decrease is noted except for the northernmost parts in winter. The intermodel agreement for the precipitation changes is lower than for temperature [21]. Giorgi and Lionello [11] estimate that significant Mediterranean rainfall decline is expected in connection with intensification of the anticyclonic circulation and a northward shift of the string of cyclonic depression areas. Alpert et al. [22] confirm a tendency of intense rainfall increase in Spain and Italy and also note an absence of trend in Israel and Cyprus. The combined effect of climate change and anthropic impact would entail a lack of water for almost 290 million people. At the same time, Algeria and Tunisia, which are part of the MENA region countries, have reached a state of absolute water scarcity.

In central Maghreb (Morocco, Algeria, and Tunisia), the rise in temperature is pursuant to the global situation. Thus, 2013 is one of the warmest years recorded in Tunisia since 1950 [23]. The rise of lowest temperatures $\left(T_{n}\right)$ is however more evident in this part of North Africa [24-26]. Rainfall data of some terrestrial observations networks, on the south shore of the western Mediterranean basin, confirm this change for the last decade. However, the results show a contrary trend to climate models predictions [27, 28]. The first authors assign a tropical precipitation origin to the return of rains observed at the Moroccan stations of Safi and El-Jadida, while, within the whole of the central region of Morocco, drought conditions prevail. In the Middle Moroccan Atlas, a situation may be noted which differs from that described for the central Moroccan region [29]. Finally, Khomsi et al. [30] find no statistical significancy in the cumulative and extreme rainfall trends (summer and winter events) in 9 stations of this last country. In Tunisia, recent studies [31] show that annual precipitation trend is on the rise for 19 regions surveyed during 1977-2011. This analysis highlights a break of chronological sequences during the most characteristic periods of the great drought of the $1980 \mathrm{~s}$ (1981-1992) and a return of rains in the early 2000s (20012009). This last trend is also confirmed by [32] for northeastern Tunisia. The absence of a significant trend is however dealt with in other studies [33] over a long chronological sequence of Tunis, Manouba station. The same evolution may also be encountered in the intra-Tellian plains and basins [34]. Finally, Jebari et al. [35] have emphasized the tendency of rainfall decline and higher efficiency of solid transport and flows over 50 years' sequences (1960-2004).

This diversity of scientific opinions confirms the spatiotemporal variability of the Mediterranean pluviometry and particularly on the south shore of the basin [36, 37]. This peculiarity makes the identification of long-term significant trends difficult [38] and shows the need to study the precipitation trend according to a global regional approach which minimises the topoclimate effect and is informed of the spatiotemporal distribution of precipitation cycles.

\section{Materials and Methods}

This article aims to analyze the precipitation trend for more than forty years of measurements on a wide northern strip in central Maghreb (Morocco, Algeria, and Tunisia). Thirtyfive stations (14 in Morocco, 12 in Algeria, and 9 in Tunisia) which provide a common period of measurements were chosen for this study (1970-2013 for Algeria and Tunisia and 1970-2011 for Morocco) (Figure 1). The monthly precipitation data were provided by the Meteorological Services "The National Office of National Meteorology (ONM) for Algeria, the National Meteorological Institute (INM) for Tunisia, and the National Directorate of Meteorology (DNM) for Morocco". Quality and homogeneity of the data were tested by these services. The missing data were supplemented with information gathered from the NCDC "National Climatic Data Center" website (http://www.ncdc.noaa.gov/).

The method used for this study is the chronological graphic method of information processing (MGCTI) of "Bertin matrix" type. The MGCTI is an analytical method based on a statistical analysis and on a graphical representation of results. This method was used for the first time in 2013 [24]. The MGCTI is developed to facilitate the interpretation of the statistical results for the Mediterranean rainfall analysis, due to the high variability affecting this parameter.

The Bertin matrix was introduced to harmonize and consolidate information after the statistical treatment. The Bertin matrix is a manual and visual method of classification of information based on data. This matrix is used to group the data that have similarities according to all the criteria studied. It provides a simple and effective way to establish a multivariate typology based on observations of the user. This provides the concordant results (even rainfall character for all stations studied in the same year) but also identifies conflicting information (different characters between stations for the same year).

The MGCTI and its graphic representation allow a chronological reading and a spatial analysis of the phenomenon. This method has been successfully tested in many North African regions [28, 29, 32, 39] and in the Sahel [40]. A comparative study with the SPI (Standard Precipitation Index) method for detecting climate drought was conducted in 2015 [41]. This study showed the simplicity and clarity of 


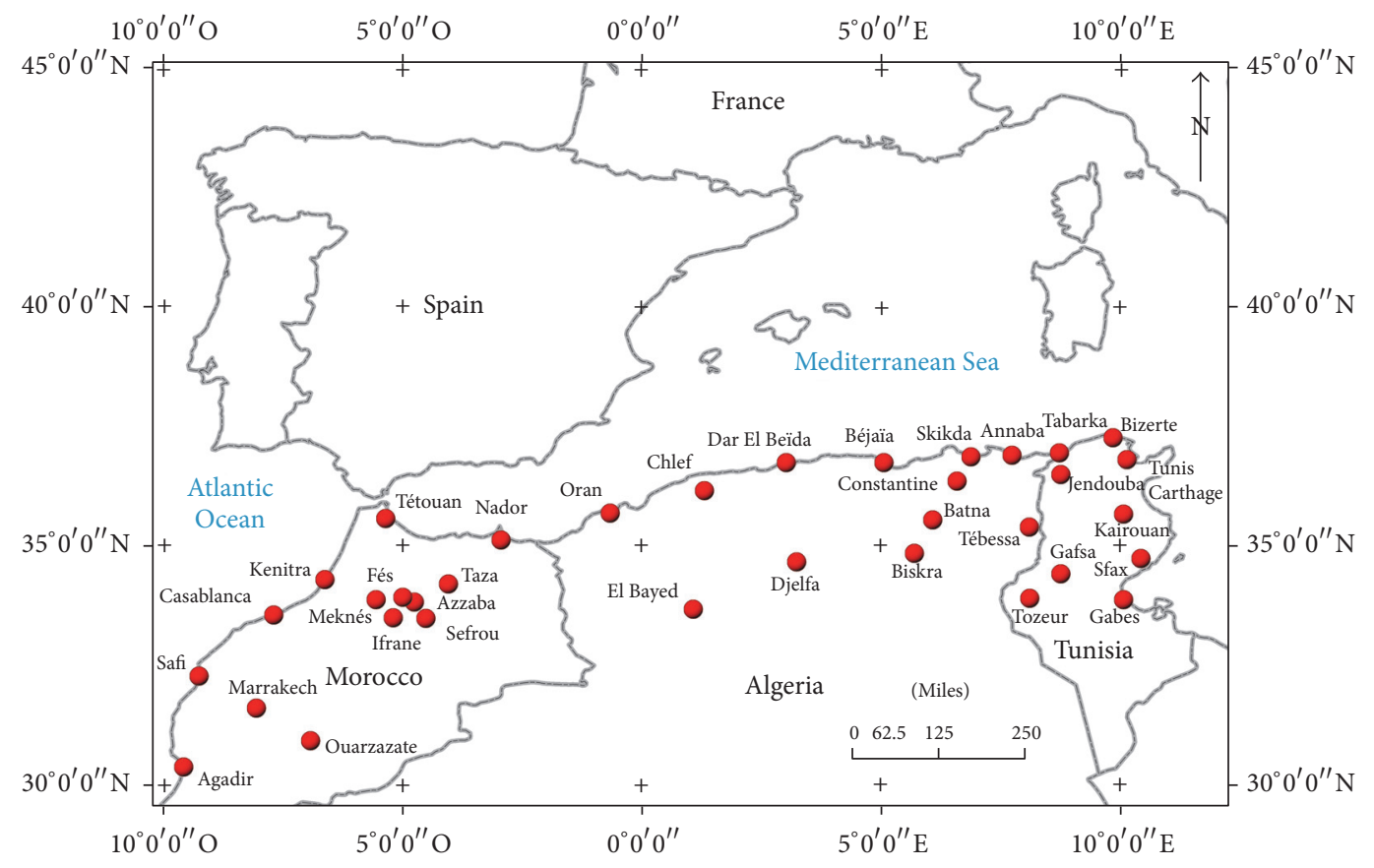

FIGURE 1: Spatial distribution of precipitation stations used for this study.

the results obtained with the MGCTI method. In this paper, we test this method on a larger area consisting of different climatic regions of North Africa (more than 30 stations). The purpose of this article is to show the trend of rainfall over nearly half a century and to detect the date of changes of cycles.

The First Stage. An annual data precipitation (cumulative rainfall over a calendar year) hierarchy in terms of limit values (Q1, Q2, Median, Q3, and Q4) is done for all stations and for the entire series (Table 1 ).

Depending on data position in relation to limit values, the years are considered as

(i) very dry, below the first quintile;

(ii) dry, between the first and the second quintile;

(iii) normal with trends towards drought, between the second quantile and the third quintile;

(iv) rainy, between the third and the fourth quintile;

(v) very rainy, above the fourth quintile.

The Second Stage. A recoding of values is made by means of a range of colours (the colour varying in terms of the annual cumulative rainfall position in relation to limit values). This first processing is followed by a reordering procedure (permutations of columns) in order to get a ranking that allows the visualisation of a homogenous coloured structure (Bertin matrix) (Figure 2). This procedure allows for the visualisation of the climate parameter evolution in terms of two dimensions (time and space).

The Third Stage. To determine the typical breaks and periods, a second procedure is conducted. It consists in assigning a number ranging from 1 (very dry year) to 5 (very wet year) according to the already determined features assigned to each year. The sum of numbers of all stations for each year is centered and reduced, thus getting a regional index (RI) varying from +1.80 for a very wet year to -1.80 for a very dry year. The "RI" is calculated as follows:

$$
\mathrm{RI}=\frac{\left(X_{i}-X\right)}{S}
$$

where $X_{i}$ is year value, $X$ is the series average, and $S$ is standard deviation.

The projection of the result on a graph allows for the visualisation of the evolution of the phenomenon on a regional scale in a first stage and, in a second stage, for the determination of data on breaks and trend change.

\section{Results and Discussion}

\subsection{Towards the End of Climatic Droughts in Central Maghreb?}

3.1.1. The Morocco Situation. The results of statistical and graphical processing of central Maghreb pluviometry show strong variability (typical of the Mediterranean climatic domain) and an organisation structured into three main climatic periods (Figure 2). 


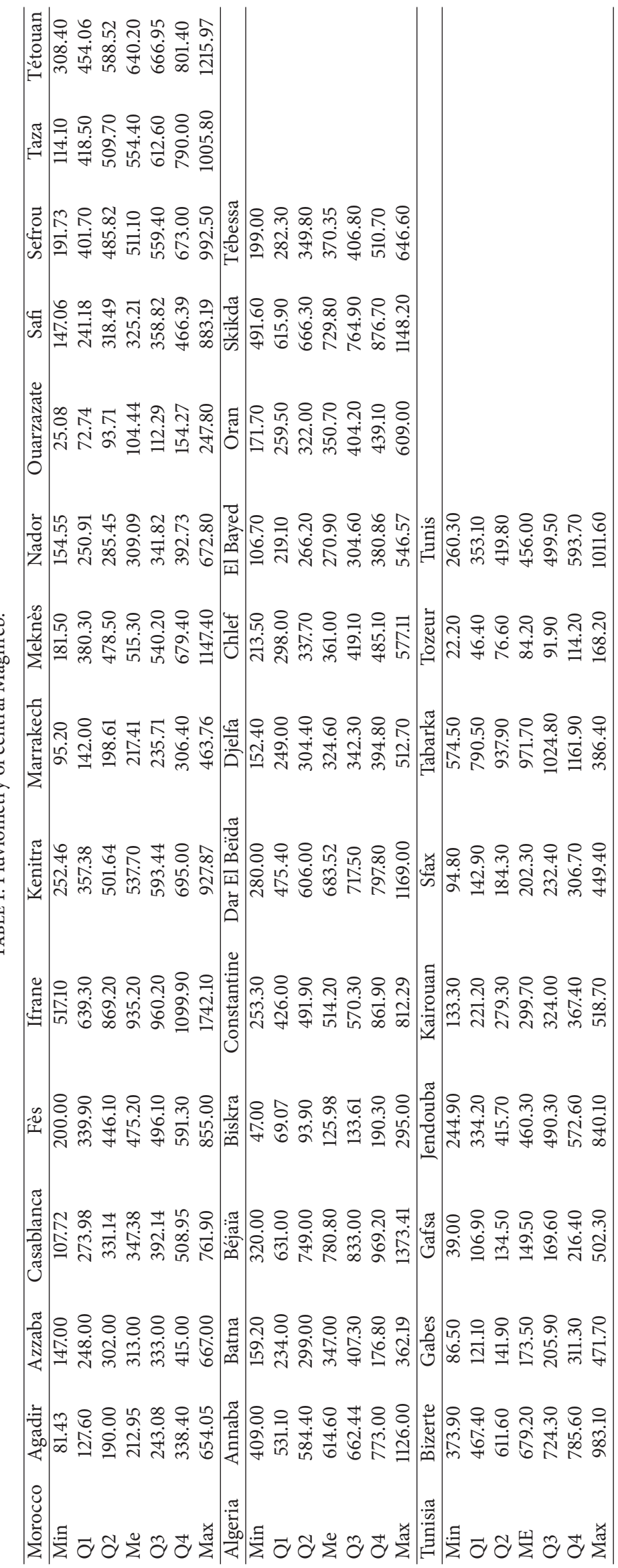




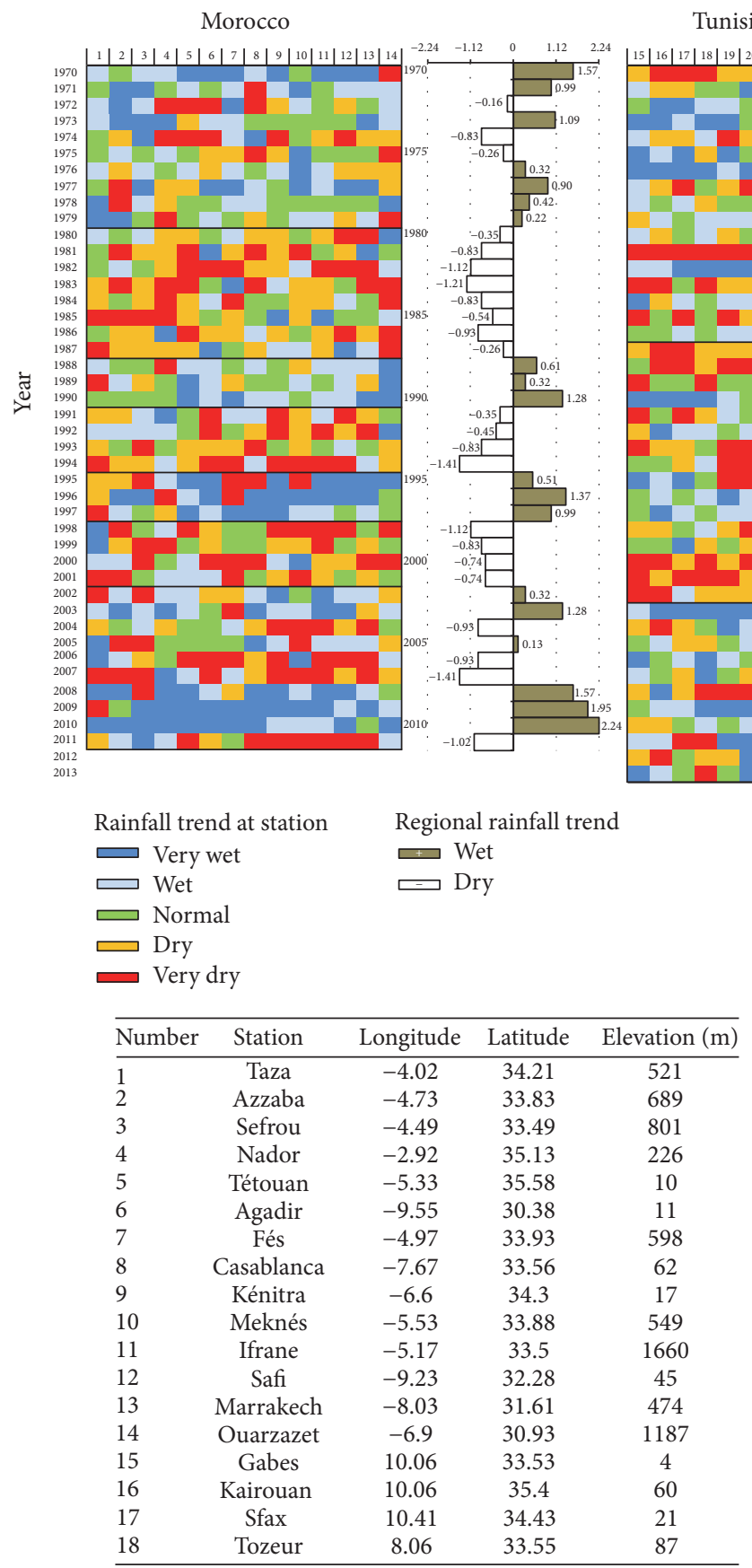

Tunisia

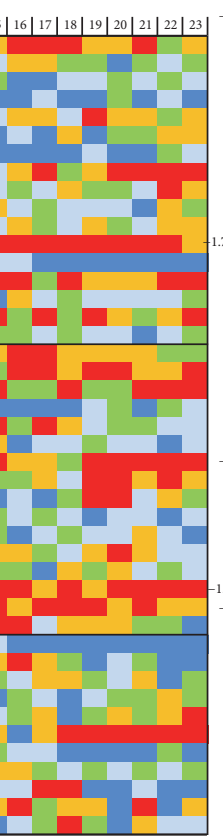

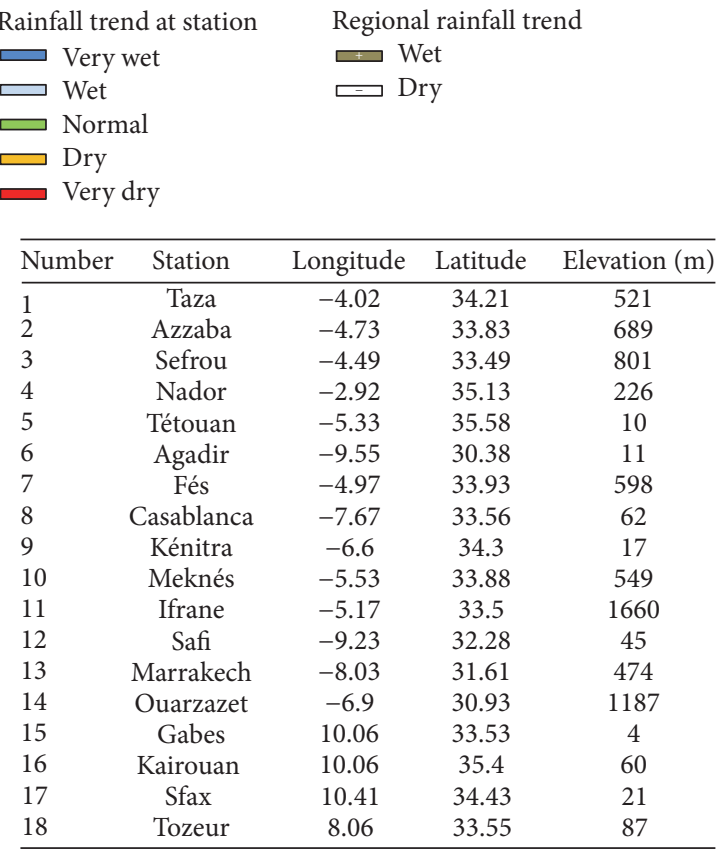

Algeria

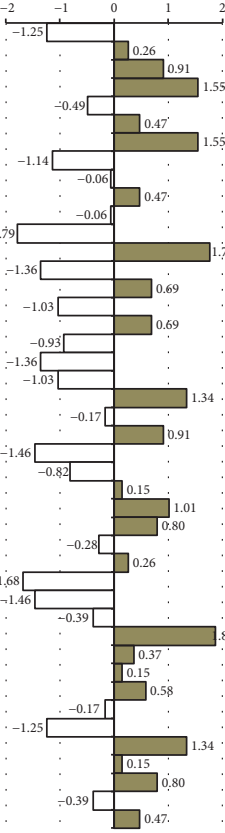

Rainfall trend at station

Very wet

$\sqsubset$ Wet

$\square$ Normal

Dry

Very dry
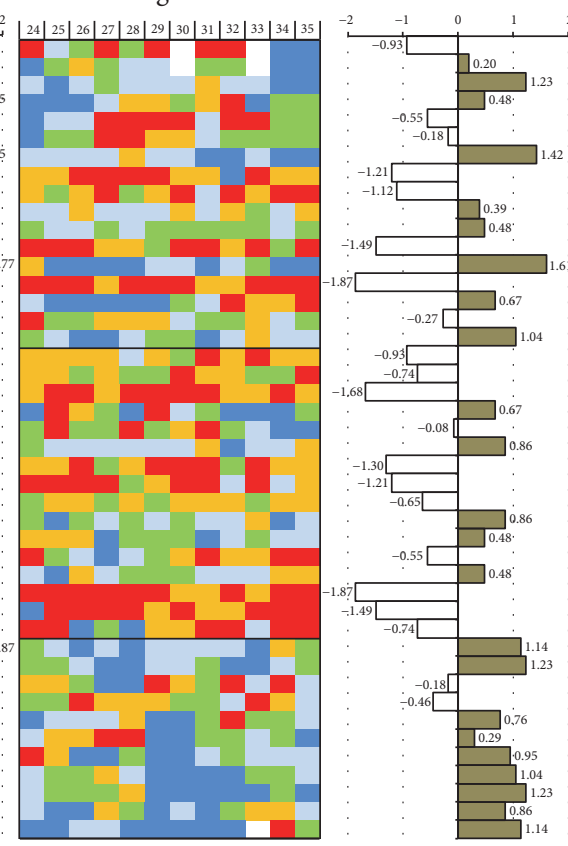

Regional rainfall trend

$\rightleftarrows$ Wet

$\Longleftarrow$ Dry

\begin{tabular}{lcccc}
\hline Number & Station & Longitude & Latitude & Elevation $(\mathrm{m})$ \\
\hline 19 & Tunis & 10.14 & 36.5 & 4 \\
20 & Bizerte & 9.48 & 37.15 & 5 \\
21 & Gafsa & 8.49 & 34.25 & 313 \\
22 & Tabarka & 8.54 & 36.58 & 66 \\
23 & Jendouba & 8.48 & 36.29 & 143 \\
24 & Oran & -0.36 & 35.38 & 90 \\
25 & Dar El Beïda & 3.13 & 36.41 & 25 \\
26 & Annaba & 7.49 & 36.5 & 8 \\
27 & Skikda & 6.54 & 36.53 & 1.3 \\
28 & Béjaïa & 5.04 & 36.43 & 1.74 \\
29 & Chlef & 1.2 & 36.13 & 143 \\
30 & Biskra & 5.44 & 34.48 & 82 \\
31 & El Bayed & 1 & 33.4 & 1341 \\
32 & Djelfa & 3.23 & 34.2 & 1180 \\
33 & Tébessa & 8.07 & 35.25 & 820.47 \\
34 & Constantine & 6.37 & 36.13 & 685 \\
35 & Batna & 6.19 & 35.45 & 822 \\
\hline
\end{tabular}

FIGURE 2: MGCTI, classification of annual precipitation according to quintiles Q1, Q2, Q3, Q4, and Q5 (measurement period from 1970 to 2013).

A period qualified as wet is visible on the matrix during 1970-1979. This decade contains $70 \%$ of the years with positive regional index. The highest values are noted at the beginning of the period (+1.57 for 1970 and +1.09 for 1973). Almost $50 \%$ of annual rainfall accumulations are considered as wet and very wet. The percentage of average year reaches $25.71 \%$, while, during dry years, it represents $27.14 \%$.

In 1980, a new drier climatic phase began and lasted until 2001 . Only $30 \%$ of the years of this long period stretching over more than two decades show a positive regional index. The proportion of dry and very dry years reaches $49.01 \%$, that of normal years $18.75 \%$, and that of rainy and very rainy years $32.23 \%$.

The regional graph allows us to distinguish three dry subperiods (negative regional index) with two rainy periods of three successive years in between:

(i) From 1980 to 1987, an uninterrupted succession of years with negative regional indices can be noted. It is a period of severe drought which marks a large part of 
the Moroccan territory. The values are relatively high for $1982(-1.12), 1983(-1.21)$, and $1986(-0.93)$. For all Moroccan stations studied, the proportion of dry and very dry years reaches almost $56 \%$, while rainy and very rainy years account for a little more than a quarter, with $24 \%$. This long period characterised by a lack of humidity is followed by three years (19881990) during which positive regional indices and a humid trend are recorded.

(ii) From 1991 to 1994, rainfall accumulations become negative again.

(iii) The regional index reaches, during this final year, one of the lowest values of the series, -1.41 .

(iv) From 1995 to 1997, a short wet period marks the Moroccan pluviometry, with a spectacular increase of pluviometry (the regional index reaches +1.37 in 1996 , one of the highest values of the first three decades of this series).

(v) The stage covering the 1998-2001 period is marked by the return of drastic conditions. A little more than $60 \%$ of rainfall accumulations recorded at various stations are considered as dry or very dry.

(vi) The last period (2002-2011) of the precipitation series is considered as wet $(60 \%$ of the years recorded a positive index). At the same time, the percentage of rainy and very rainy years at all stations reaches $52.38 \%$. The last years of the series provide evidence of change of trend for this decade. Indeed, from 2008 to 2010 , the percentage of rainy and very rainy years goes from $78.57 \%$ to $85.71 \%$ and $92.85 \%$.

3.1.2. The Algeria Situation. The MGCTI graphical matrix (Figure 2) shows, for Algeria, an organisation of rainfall accumulations into three characteristic periods.

A first stage of strong variability in 1970-1986. No genuine climatic trend stands out in this period. All stations under study are characterised by an almost even distribution of extreme classes of annual rainfall, rainy and very rainy (40\%), dry and very dry (39.50\%), and normal (20.5\%). The regional index is negative for more than $47 \%$ of the years as opposed to $52.94 \%$ for positive values. What is remarkable about this period is undoubtedly a powerful interannual oscillation between dry year and wet year. A sequence of three rainy years (1971-1973) can be noted at the beginning of the series, while, for the rest of the period, trend inversions (dry year, rainy year) are for two successive years at most.

A second stage starts in 1987 and finishes in 2002. It is marked by a drying trend because $55.60 \%$ of the years are considered to be dry and very dry, while rainy and very rainy years totalize no more than $26.58 \%$. At the same time, the regional index is negative for almost $68 \%$ of this period as compared to $31.25 \%$ for positive values. The persistence of drought conditions never exceeds three consecutive years. Extreme negative values for this dry stage are recorded in 1989 (-1.68), $2000(-1.87)$, and $2001(-1.49)$.

The last period of this precipitation series (2003-2013), in which $82 \%$ of the years have a positive regional index, is described as rainy. On the whole, this last stage distinguishes itself through an uninterrupted sequence of 7 years (20072013) with positive regional indices. The percentage of rainy and very rainy years recorded at all stations $(55.72 \%)$ is in net increase, while dry and very dry years, with $20.61 \%$, are in net decrease as compared to the previous period.

3.1.3. The Tunisia Situation. Precipitation data recorded in 1970-2013 in Tunisia (Figure 2) are characterised by a significant variability previously emphasized during the study of Morocco and Algeria series. The MGTCI graphical matrix shows once more three major characteristic periods:

(i) The first stage starts in 1970 and finishes in 1986 and is marked by a lack of trend. The regional index is positive for almost $53 \%$ of years and negative for the remaining $47 \%$. The percentages calculated at all stations for wet and very wet classes show that almost $42 \%$ of years belong to this precipitation category. The dry and very dry classes represent just over 39\% of years. This first period, just like that analyzed for Algeria, is characterised by an important variation of extreme years (two years, namely, 1981 with a negative index of $-1.79 \%$ and 1982 with a positive index of +1.77 , show this particularity). The beginning of the period tends less to this oscillation (a sequence of three rainy years is noticeable from 1971 to 1973).

(ii) The second period is marked by a dry trend which lasts 16 years on this territory. The regional index shows that almost $63 \%$ of years record a negative value. The years belonging to the dry and very dry class totalize almost $55 \%$ for all stations. Rainy and very rainy years only account for $22.90 \%$. Successive stages with the same trends exceed no more than three years (1987-1989 and 2000-2003 for negative indices and 1995-1997 for positive indices). Four years stand out through negative indices which exceed -1: 1988 (-1.36), 1989 (-1.03), 1993 (-1.46), 2000 (-1.68), and $2001(-1.46)$.

(iii) The last period (2003-2013) is considered wet. The regional index is positive for a period of 8 years. The return of drought conditions is noted in 2007, in 2008 (index above -0.5), and in 2012 (index equal to -1.25). Rainy and very rainy years are evaluated for this phase at almost $48 \%$, while dry and very dry years totalize $31.31 \%$. These numbers thus indicate an increase of years in the first class of $+25 \%$ as compared to the previous period and a regress of the arid and very arid class of $-23.64 \%$.

3.2. A Net Increase of Rainy and Very Rainy Years for the Decade 2002-2011. Figure 3 was completed by starting from the decennial averages of the categories of rainy and very rainy, dry and very dry years, and normal averages, calculated for the 1982-2011 interval, confirming the previous arguments for the return of rainfall conditions in central Maghreb.

(i) The analysis of the decade 1982-1991 (map shown in Figure 3(a)) shows the predominance of drought 


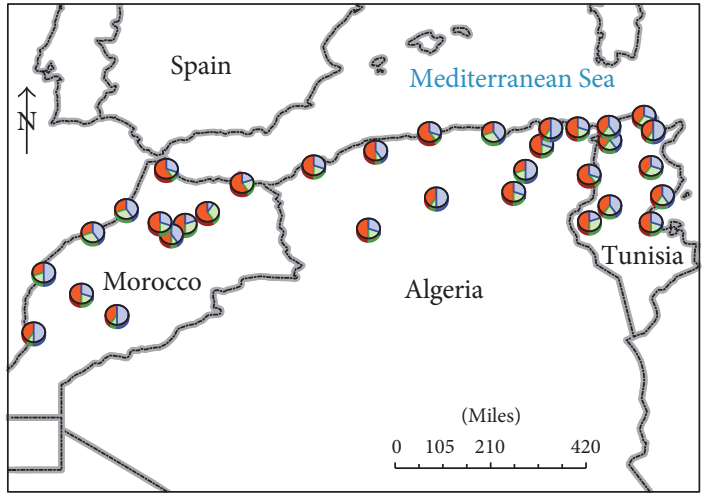

Q

$\square$ Rainy and very rainy years

$\square$ Normal year

Dry and very dry years

(a) $1982-1991$

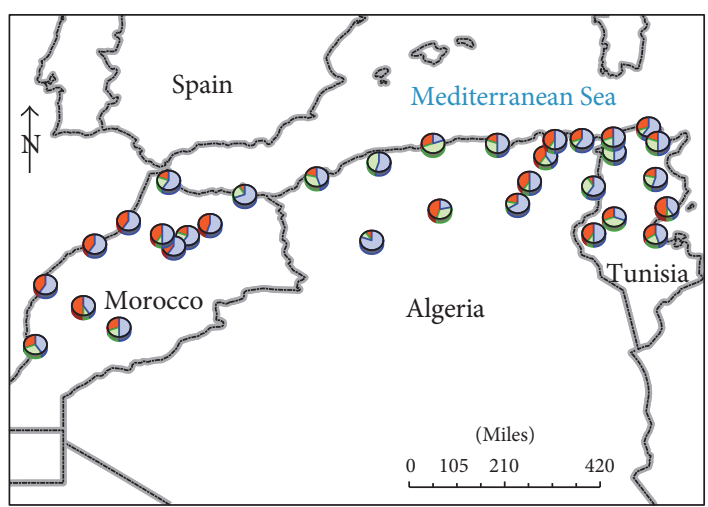

잉

Rainy and very rainy years

Normal year

Dry and very dry years

(c) 2002-2011

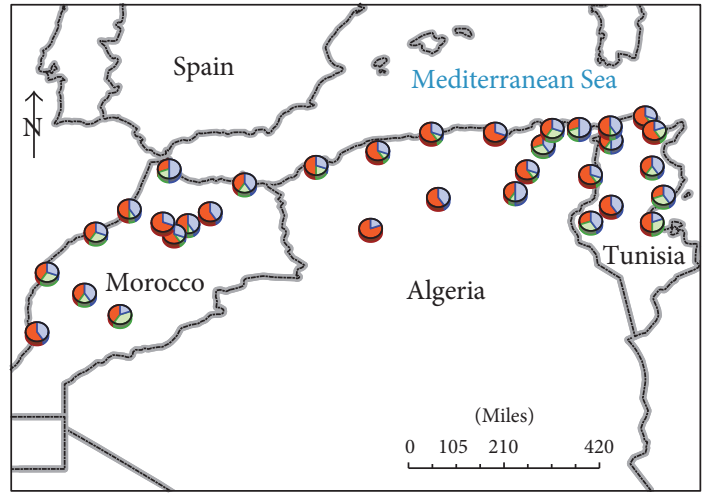

(2)

$\square$ Rainy and very rainy years
Normal year
Dry and very dry years

(b) $1992-2001$

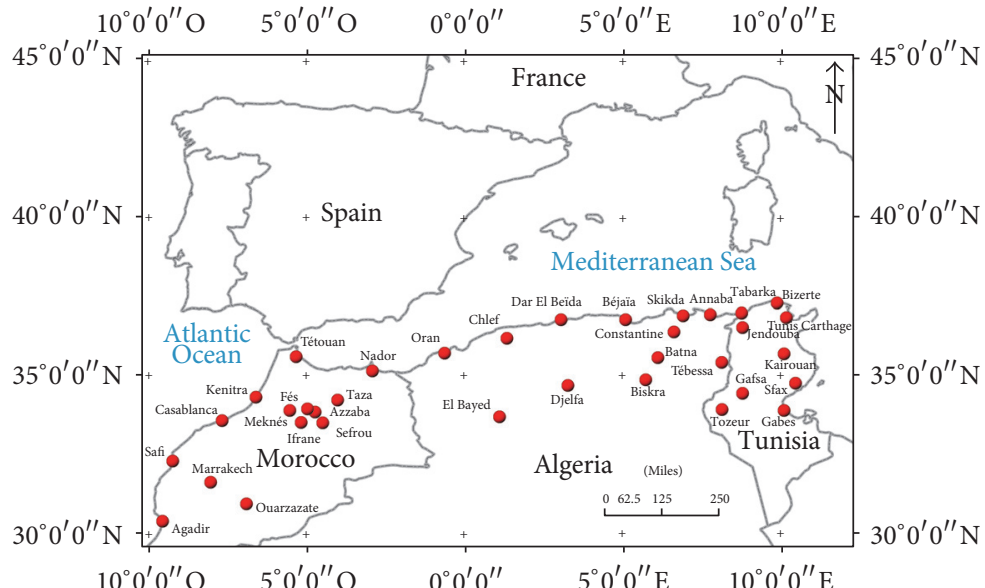

FIGURE 3: The evolution of precipitation accumulations of extreme years (1982-2011).

conditions in nineteen stations which record more than $50 \%$ dry and very dry years and only 7 which correspond to wet and wetter conditions for a little over a half of the duration of the period studied.

(ii) The 1992-2001 period (map shown in Figure 3(b)) shows a more drastic precipitation situation with 21 stations that display rainfall accumulations from the dry to the very dry category of over $50 \%$. At the same time, one may note the low values of rainy and very rainy years that reach $50 \%$ only at Skikda, Biskra, and Tétouan and are below this level at the remaining stations.

(iii) The analysis of the map shown in Figure 3(c) for the 2002-2011 period of measurements clearly illustrates the predominance of rainy and very rainy years at most stations (25). Dry years reach $50 \%$ only at three stations (Marrakech, Sefrou, and Sfax). As for rainy years, they exceed $40 \%$ at all stations, except Dar el Beïda, Djelfa, and Gafsa.

The last map (Figure 4) displays the differences between the last two decades (1992-2001 and 2002-2011), between precipitation accumulations of rainy and very rainy years and dry and very dry years. This graphical representation allows us to see the evolution of extreme rainfall for the two already discussed periods. It reveals the importance of positive differences which indicate an increase of the former category in $83 \%$ of the stations. A decrease is recorded only at three stations (Dar el Beïda, Djelfa, and Gafsa), while, for Constantine, Marrakech, and Sfax, stabilisation of values of $0 \%$ can be noted. This map confirms a return of more 


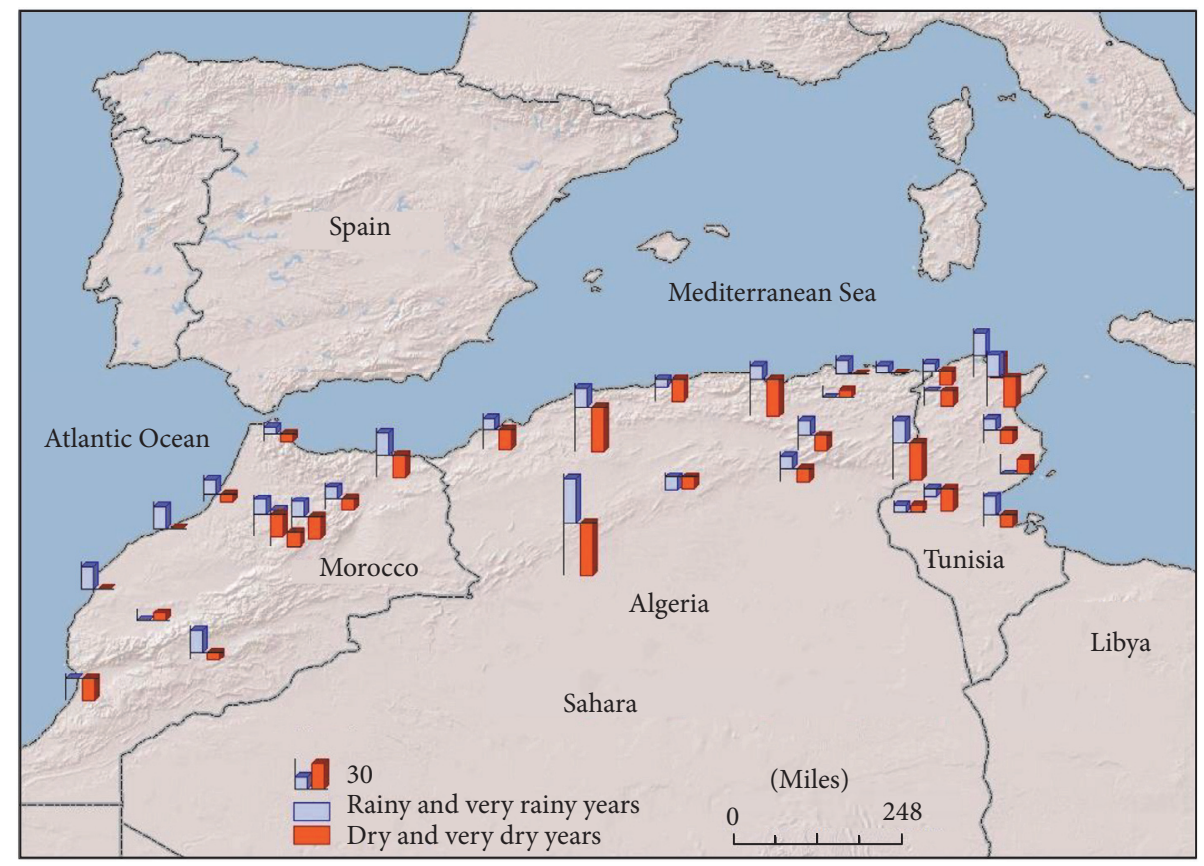

FIGURE 4: Differences between the last two decades (rainy and very rainy years and dry and very dry years).

favorable conditions throughout the entire territory, as the decrease of dry and very dry years is common at $29 \%$ of the stations (of which $14 \%$ show stabilisation of this category of humidity for the two decades).

(i) In Tunisia, southern stations (Sfax and Tozeur) do not follow this trend and are characterised by a rise in the percentage of dry and very dry years of $+20 \%$ and $+10 \%$, respectively.

(ii) In Algeria, the Constantine, Annaba, and Skikda stations located in the east of the country record a rising trend of $10 \%$ for the first station and stabilisation of values for the last two.

In Morocco, only one station (Marrakech) is not keeping up with the return of rainy conditions as it records a rise in dry and very dry years of $10 \%$. On the Atlantic coast, Casablanca and Safi are the other two stations in this vast country that manifest a stable trend of extreme years regarding this last category.

The processing of the trend of extreme years from 1970 to 2013 (the percentage of stations which recorded a rainy and very rainy year, dry and very dry year or a normal one) for the three countries confirms previous results.

We can see in Figure 5(a) that, since the 2000s, the percentage developed for dry and very dry years has been clearly in constant decline in all three countries. At the same time, rainy and very rainy years show a rising trend confirmed starting with this last date (Figure 5(b)). Figure 5(c) concerning the class of normal years allows one to note that the percentage of stations, after displaying a trend of decrease from 1995 to 2000, increases starting with this last date for
Algeria and Tunisia but decreases for Moroccan stations, which confirms a steady return of the wet stage in this country (considering the previously developed arguments for the other two classes).

The analysis of precipitation evolution in central Maghreb (Morocco, Algeria, and Tunisia) revealed a significant variability typical of the Mediterranean climate (which is stronger for the last two countries). A first wet period marks the precipitation series in Morocco (1970-1979) while, in the other two countries, from 1970 to 1986, no significant trend can be noted. This study also allowed us to highlight the durable and drastic nature of the climatic drought affecting Morocco for more than two decades (1980-2001). Indeed, precipitation deficits in these countries are intense and may persist for long periods of time (1980-1987, 1991-1994, and 1998-2001). Climatic drought recorded in Algeria and Tunisia is shorter (1987-2002) and the cycles of years of deficits not only are synchronised between the two countries but also are less extended in time and they never exceed three consecutive dry years (1987-1989, 1993-1994, and 2000-2002).

Finally, the rainfall return period is generalised in the Maghreb area under study. Starting with 2002 in Morocco and 2003 in Algeria and Tunisia, values confirm a return towards more rainy conditions, despite the persistence of extreme variability which is characterised by a brief return of dry and very dry years (2006 and 2008).

This new period marks a break from past droughty periods despite the return, once in a while, of deficient years (e.g., in 2005 and 2006 for Algeria and Tunisia and 2006, 2007, and 2011 for Morocco).

Figure 6, developed starting from the mobile average of all stations studied, sums up the main 3 stages that have 


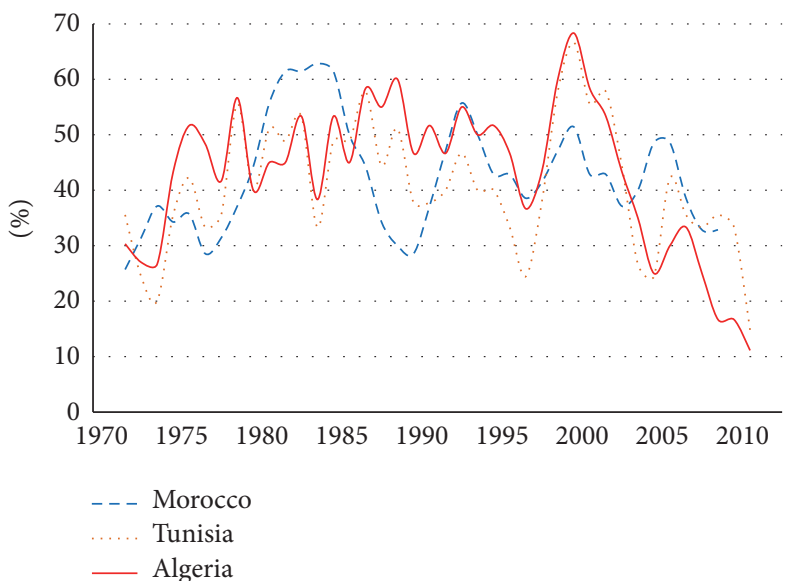

(a)

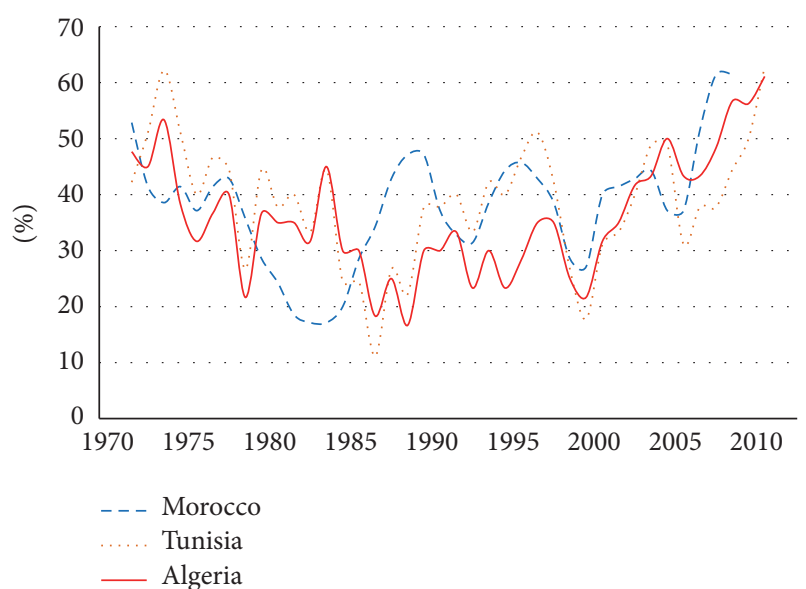

(b)

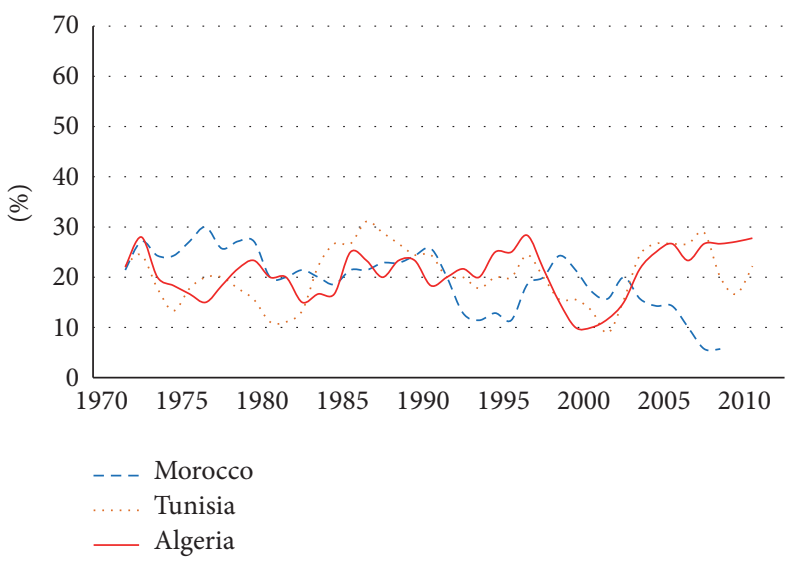

(c)

FIGURE 5: Mobile frequency averages of stations that recorded dry and very dry years (a), rainy and very rainy years (b), and normal years (c) (1970-2011 for Morocco and 1970-2013 for Algeria and Tunisia).

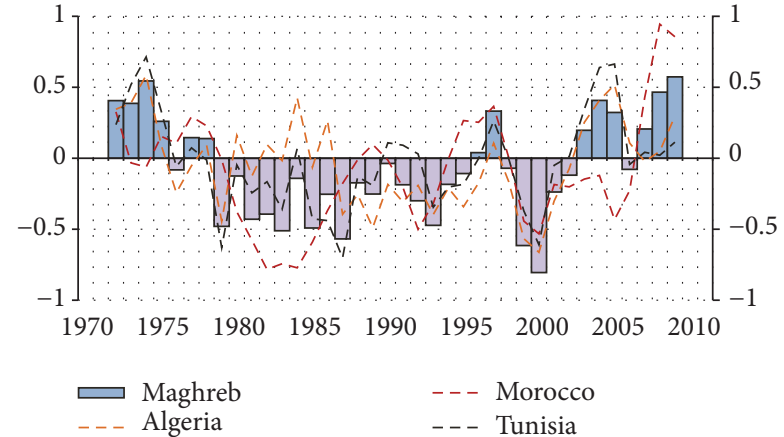

FIGURE 6: Reduced centered deviations of annual rainfall accumulations recorded in central Maghreb (mobile average calculated for 35 weather stations in 1970-2011).

affected Maghreb pluviometry during the last 44 years. The first humid stage is noticeable from 1970 to 1979 , followed by the great climatic drought which lasts almost a half a century and, finally, the rainfall return which can be noted as of 2003 .
Thus, south coast regions of western Mediterranean basin have been subjected, in the last years, to strong climate disturbances (these facts are not concordant with the results of climate patterns already cited for precipitations). The signs of change are extremely eloquent for the latest years in all this region of North Africa, as evidenced by the rainfall observed between September 2008 and September 2009 In Morocco [42]. The 2009-2010 rainfalls are also considered as exceptional and historic because they allowed for the filling of dams at their maximum capacity (the filling rate of the Al Wahda Dam, the largest of the kingdom, located in the Ouergha Wadi, was 98.5\%). These rains ensured a record cereal production of 80 million quintals (for 2009/2010). This trend was confirmed for 2012/2013 because, with an average pluviometry of $450 \mathrm{~mm}$, the excess rainfall on a national scale amounts to $+20 \%$ as compared to a normal year [42]. At the same time, this agricultural campaign ensured a new record cereal production evaluated at 97 million quintals. For 2014, the filling of dams in operation reached nationwide a level of $72.38 \%$, while westward, in areas that were affected by disturbances, an exceptional percentage of filling of $87 \%$ was noted. In the Moroccan South, observation data revealed a return 
towards more humid conditions in the Tafilet oasis [4346] and a reinstatement of several "Foggaras" (a traditional hydraulic system affected by past climatic droughts). At times, this rainfall return occurs in extreme episodes as was the case of the recent floods (November 2014) which hit central and south-western Morocco (Agadir, Guelmin, and Marrakech areas). In the first area, rains recorded very high intensities ( $250 \mathrm{~mm}$ in 3 days from the 28th to the 30th of November 2014), which represents almost $90 \%$ of the observed average annual accumulation $(280 \mathrm{~mm})$.

As regards Algeria, the situation seems similar because the 2008/2009 agricultural campaign was described as highly satisfactory and the cereal production recorded the following year $(2009 / 2010)$ is a record of 61.2 million quintals that has never been equalled. The hydrological situation is as satisfactory as in Morocco, judging by the Ministry of Agriculture publications: an unprecedented dam filling up which amounted to nearly $72 \%$ in 2010 and $81 \%$ in April 2013 for the 65 dams in operation and to $80.4 \%$ in March 2014 , levels that had never been reached hitherto. The effects of climate changes are also manifested in this country by extreme events (a succession of hot episodes in 2015 with a threshold temperature of $50^{\circ} \mathrm{C}$ exceeded at Ourgla on August 2nd 2015 and of snowfall in the Assekrêm mountains in Hoggar massif located in southern Algeria, a very rare fact never observed since 1945).

In Tunisia, the situation is less obvious because threequarters of the country have an arid and semiarid climate. This new trend is still noticeable through a rise in intense precipitation events and a net increase of the number of floods (Sfax city very well illustrates this; the city was flooded twice in 1969 and 1982 and, despite important improvement works carried out in 1984 and the past years, it was flooded again in 2009 and 2013) [47].

\section{Conclusions}

To conclude, we may say that the climate change observed during the last years is characterised by a rainfall return but with a far greater intensity. In Algeria, the severe disturbances (which lead to a pluviometry of over $30 \mathrm{~mm} / 24 \mathrm{~h}$ ) are on the rise in the last years (data, ONM). This again is not concordant with the IPCC conclusions which point out a decrease of disturbances over the Mediterranean space. At the same time, the temperature trend continues to be rising (despite a slight cooling of values recorded during the last years).

The variability of short-term global climate is generally associated with coupling phases of oceanic and atmospheric phenomena including El Niño Southern Oscillation (ENSO) and the North Atlantic Oscillation (NAO). While El Niño Southern Oscillation (ENSO) affects climate variability in the world, the North Atlantic Oscillation (NAO) is the climate model dominant in the North Atlantic region. The latter cyclic oscillation whose role is still under debate could explain the variability of rainfall in much of the Mediterranean area and support the hypothesis of a return of the rains marking the end of years of drought in central Maghreb
Further analysis of the response of rainfall to the North Atlantic Oscillation shows that drought seems more in line with the positive indicators of high intensity, demonstrating greater strengthening of the pressure in Azores and weakening of the Icelandic Low pressure. Under these conditions, the depressions are pushed towards northern latitudes, which promotes the establishment of a dry and mild weather on the periphery of the Mediterranean basin and North African regions.

When the signal fades or becomes negative, the pressure associated with the Azores high is lower compared to the normal value and, at the same time, the Icelandic Low is barely formed. According to this mode of traffic, the depressions corridor withdraws further south and thus affects the Mediterranean regions of the south shore which will be wetter.

This return of rainfall over central Maghreb, should it be confirmed, could mean the end of several decades of recurrent droughts and announce a durable return to "the normal." This assumption is supported by emphasizing the impact of different world climate oscillations (North Atlantic Oscillation; El Niño Southern Oscillation) for all the continents and particularly for the African continent $[27,48]$. Do these facts announce a new climate phase which marks a break from past drastic conditions? Such question is difficult to answer today, but climate data and information concerning the hydraulics and agriculture of Maghreb confirm a completely unique situation in this vast area of North Africa.

Faced with such great changes that today affect the Maghreb region and given the complexity of spatial and temporal dimensions of the climatic signal, a more thorough research of causes and retroactions would allow for a better understanding of the mechanisms behind this new trend. These investigations should integrate and quantify the role of terrigenous aerosols in the dynamics of local climate and show the importance of sea surface temperatures in regulating rainfall.

\section{Additional Points}

Check the following websites:

WMO, World Meteorological Organisation: http:// www.wmo.int/pages/index_en.html

ONM, Office National de la Météorologie (Algeria): http://www.meteo.dz/

Direction de la Météorologie Nationale (Morocco): http://www.marocmeteo.ma/

IMN, Institut de la Météorologie Nationale (Tunisia): http://www.meteo.tn/default.html

NCDC, National Climatic Data Center: http://www .ncdc.noaa.gov/

\section{Competing Interests}

The authors declare that they have no competing interests. 


\section{References}

[1] IPCC (Intergovernmental Panel on Climate Change) GIEC, Changements climatiques en 2013, Les éléments scientifiques, résumé à l'intention des décideurs, service d’appui technique du groupe de travail I GTI, 2013, https://www.ipcc.ch/pdf/ assessment-report/ar5/wg1/WG1AR5_SummaryVolume_FINAL_ FRENCH.pdf.

[2] NOAA, National Climatic Data Center, State of the Climate, Global Analysis for Annual 2014, 2015, http://www.ncdc.noaa .gov/sotc/global/2014/13.

[3] WMO (Wolrd Meteorological Organization), "Hotter, drier, wetter. Face the future," Bulletin, vol. 65, no. 1, p. 64, 2016.

[4] Wolrd Meteorological Organization (WMO), Statement on the Status of Global Climate in 2012, 2013.

[5] M. H. I. Dore, "Climate change and changes in global precipitation patterns: what do we know?" Environment International, vol. 31, no. 8, pp. 1167-1181, 2005.

[6] L. V. Alexander, X. Zhang, T. C. Peterson et al., "Global observed changes in daily climate extremes of temperature and precipitation," Journal of Geophysical Research Atmospheres, vol. 111, no. 5, Article ID D05109, pp. 1-22, 2006.

[7] M. New, M. Todd, M. Hulme, and P. Jones, "Precipitation measurements and trends in the twentieth century," International Journal of Climatology, vol. 21, no. 15, pp. 1899-1922, 2001.

[8] J. H. Christensen, B. Hewitson, A. Busuioc et al., "Regional climate projections," in Climate Change 2007: The Physical Sciences Basis. Contribution of Working Group I to the Fourth Assessment Report of the Intergovernmental Panel on Climate Change, S. Solomon, D. Qin, M. Manning et al., Eds., chapter 11, pp. 847-940, Cambridge University Press, Cambridge, UK, 2007, https://www.ipcc.ch/pdf/assessment-report/ar4/wg1/ar4wg1-chapterl1.pdf.

[9] S. Planton, M. Déqué, H. Douville, and B. Spagnoli, "Impact du réchauffement climatique sur le cycle hydrologique," Comptes Rendus Geoscience, vol. 337, no. 1, pp. 193-202, 2005.

[10] F. Giorgi, "Climate change hot-spots," Geophysical Research Letters, vol. 33, no. 8, 2006.

[11] F. Giorgi and P. Lionello, "Climate change projections for the Mediterranean region," Global and Planetary Change, vol. 63, no. 2-3, pp. 90-104, 2008.

[12] Blue Plan, Environment and development in Mediterranean, Climate change in the Mediterranean, no. 9, pp. 4, 2008.

[13] E. Xoplakie, Climate variability over the mediterranean [Ph.D. thesis], University of Bern, Bern, Switzerland, 2002.

[14] P. Lionello, J. Bhend, A. Buzzi et al., "Cyclones in the Mediterranean region: climatology and effects on the environment," in Mediterranean Climate Variability, P. Lionello, P. MalanotteRizzoli, and R. Abd Boscolo, Eds., pp. 324-372, Elsevier, Amsterdam, The Netherlands, 2006.

[15] F. Jin, A. Kitoh, and P. Alpert, "Water cycle changes over the Mediterranean: a comparison study of a super-high-resolution global model with CMIP3," Philosophical Transactions of the Royal Society A: Mathematical, Physical and Engineering Sciences, vol. 368, no. 1931, pp. 5137-5149, 2010.

[16] C. C. Raible, B. Ziv, H. Saaroni, and M. Wild, "Winter synopticscale variability over the Mediterranean Basin under future climate conditions as simulated by the ECHAM5," Climate Dynamics, vol. 35, no. 2-3, pp. 473-488, 2010.

[17] S. O. Krichak, J. S. Breitgand, R. Samuels, and P. Alpert, "A double-resolution transient RCM climate change simulation experiment for near-coastal eastern zone of the Eastern Mediterranean region," Theoretical and Applied Climatology, vol. 103, no. 1, pp. 167-195, 2011.

[18] C. M. Philandras, P. T. Nastos, J. Kapsomenakis, K. C. Douvis, G. Tselioudis, and C. S. Zerefos, "Long term precipitation trends and variability within the Mediterranean region," Natural Hazards and Earth System Sciences, vol. 11, no. 12, pp. 3235-3250, 2011.

[19] M. Giannakopoulos, M. Bindi, M. Moriondo, and T. Tin, "Climate change impacts in the Mediterranean resulting from a $2^{\circ} \mathrm{C}$ global temperature rise," A Report for WWF, http://www .fao.org/fileadmin/user_upload/rome2007/docs/Climate_Change_ Adaptation_Water_Sector_NENA.pdf.

[20] G. Tselioudis, C. Zerefos, P. Zanis, P. Repapis, and I. Kapespmenakis, "Future trends in Mediterranean precipitation and possible connections with the phase pf the North Atlantic Oscillation," in Proceedings of the 9th Conference of Meteorology, Climatology and Atmospheric Physics, pp. 513-520, Thessaloniki, Greece, May 2008.

[21] M. Dubrovský, M. Hayes, P. Duce, M. Trnka, M. Svoboda, and P. Zara, "Multi-GCM projections of future drought and climate variability indicators for the Mediterranean region," Regional Environmental Change, vol. 14, no. 5, pp. 1907-1919, 2014.

[22] P. Alpert, T. Ben-Gai, A. Baharad et al., "The paradoxical increase of Mediterranean extreme daily rainfall in spite of decrease in total values," Geophysical Research Letters, vol. 29, no. 11, pp. 1-31, 2002.

[23] WMO (Wolrd Meteorological Organization), "Statement on the status of global climate in 2012," Tech. Rep. 1108, 2013.

[24] Z. Nouaceur, B. Laignel, and I. Turki, "Changements climatiques au Maghreb: vers des conditions plus humides et plus chaudes sur le littoral algérien ?" Physio-Géo, vol. 7, pp. 307-323, 2013.

[25] Z. Nouaceur, B. Laignel, and I. Turki, "Changement climatique en Afrique du Nord: vers des conditions plus chaudes et plus humides," in dans le Moyen Atlas Marocain et Ses Marges Actes du XXVII Colloque International de Climatologie, pp. 399-405, Dijon, France, 2014.

[26] M. G. Donat, T. C. Peterson, M. Brunet et al., "Changes in extreme temperature and precipitation in the Arab region: longterm trends and variability related to ENSO and NAO," International Journal of Climatology, vol. 34, no. 3, pp. 581-592, 2014.

[27] A. Sebbar, W. Badri, H. Fougrach, M. Hsain, and A. Saloui, "Étude de la variabilité du régime pluviométrique au Maroc septentrional (1935-2004)," Sécheresse, vol. 22, no. 3, pp. 139148, 2011.

[28] Z. Nouaceur, "Évaluation des changements climatiques au Maghreb, Étude du cas des régions du quart nord-est algérien," in Proceedings of the Actes du 23rd Colloque de l'Association Internationale de Climatologie, 'Risques et Changements Climatiques', pp. 463-468, Rennes, France, 2010.

[29] M. Amyay, Z. Nouaceur, A. Tribak, Kh. Okba, and A. Taous, "Caractérisation des évènements pluviométriques extrêmes dans le Moyen Atlas marocain et ses marges," in Actes du XXV ème Colloque International de Climatologie, pp. 75-80, Grenoble, France, 2012.

[30] K. Khomsi, G. Mahe, Y. Tramblay, M. Sinan, and M. Snoussi, "Trends in rainfall and temperature extremes in Morocco," Natural Hazards and Earth System Sciences Discussions, vol. 3, no. 2, pp. 1175-1201, 2015. 
[31] M. Kortli, Changement climatique, eau et santé en Tunisie [Mémoire de Master], Institut National Agronomique de Tunisie, INRGREF, Tunis, 2012.

[32] B. Laignel, Z. Nouaceur, H. Jemai, H. Abida, M. Ellouze, and I. Turki, "Vers un retour des pluies dans le nord-est tunisien?" in Proceedings of the Actes du XXVIIe Colloque de l'Association Internationale de Climatologie-2 au 5 Juillet 2014, pp. 727-732, Dijon, France, 2014.

[33] N. Fehri, "Laggravation du risque d'inondation en Tunisie: éléments de réflexion," Physio-Géo, vol. 8, pp. 149-175, 2014.

[34] L. Henia and Z. Hlaoui, "La pluviométrie dans les plaines et bassins intratelliens en Tunisie: évolution récente et projection dans le futur," in Climat Montagnard et Risques, Actes du XXIVème Colloque de l'AIC (Rovereto), M. Fazzini and G. Beltrando, Eds., pp. 303-308, AIC et Université de Ferrare, 2011.

[35] S. Jebari, R. R. Berndtsson, F. Lebdi, and A. Akissa Bahri, "Sediment, discharge and precipitation variation in the wadi Mellegue catchment during the 50 past years, Actes des dixièmes Journées Scientifiques de l'INRGREF, Hammamet 2122 novembre 2007 Exploitation des ressources en eau pentru une agriculture durable," Annales de l'INRGREF, vol. 11, pp. 116$122,2008$.

[36] C. Norrant, Tendances pluviométriques indicatrices d'un changement climatique dans le bassin méditerranéen de 1950 à 2000. Étude diagnostique [Ph.D. thesis], Université Aix Marseille I, Université de Provence, Marseille, France, 2004.

[37] C. Norrant-Romand and A. Douguédroit, "Significant rainfall decreases and variations of the atmospheric circulation in the Mediterranean (1950-2000)," Regional Environmental Change, vol. 14, no. 5, pp. 1725-1741, 2014.

[38] E. Morin, "To know what we cannot know: global mapping of minimal detectable absolute trends in annual precipitation," Water Resources Research, vol. 47, no. 7, Article ID W07505, 2011.

[39] Z. Nouaceur, B. Laignel, and I. Turki, "Changement climatique en Afrique du Nord : vers des conditions plus chaudes et plus humides, dans le Moyen Atlas Marocain et ses marges," in Proceedings of the Actes du XXVII Colloque International de Climatologie, pp. 399-405, Dijon, France, 2014.

[40] Z. Nouaceur, B. Laignel, and I. Turki, "Changement climatique au Sahel: des conditions plus chaudes et plus humides en Mauritanie?” Sécheresse, vol. 24, pp. 85-95, 2013.

[41] Z. Nouaceur and B. Laignel, "Caractérisation des évènements pluviométriques extrêmes sur la rive Sud du bassin méditerranéen: étude du cas du quart nord-est algérien," in Proceedings of the Actes du XXVIII Colloque International de Climatologie, pp. 573-578, Liège, Belgium, 2015.

[42] Ministry of Energy, Mines, Water and Environment, Ministère de l'Energie, des Mines, de l'Eau et de l'Approvisionnement, 2008-2009, 2009-2010, 2010-2011, 2011-2012, 201-2013. Situation des ressources en eau et du remplissage des barrages durant l'année hydrologique, Direction de la Recherche et de la Planification de l'eau, 9 p (Maroc, Morocco), http://www.mem.gov .ma/.

[43] R. Thierry, Au fond de la khettara Lahloua, Le journal de l'IRD, IRD, Institut de recherche pour le développement, juin/juillet/août, no. 40, pp. 16, 2007.

[44] M. El Faiz and T. Ruf, "An introduction to the khettara in morocco: two contrasting cases," in Proceedings of the 1st WATARID International Conference on Water, Ecosystems and Sustainable Development in Arid and Semi-Arid Areas (WATARID '06), G. Schneier-Madanes and M.-F. Courel, Eds., pp. 151-163, Springer, Ürümqi, China, October 2006.
[45] Institut de Recherche pour le Développement (IRD), "Les réseaux d'eau anciens ressuscitent en Méditerranée," Actualité Scientifique 370, 2011.

[46] M. Mahdane, S. Lanau, Th. Ruf, and M.-J. Valony, Gouvernance d'une oasis dont l'eau provient quasi exclusivement de l'exploitation traditionnelle des galeries drainantes, les khettaras: le cas de SKOURA au Maroc, Atelier international à Tunis 4-6, Novembre 2010.

[47] A. Daoud, "Retour d'expérience sur les inondations dans l'agglomération de Sfax (Tunisie méridionale) de 1982 à 2009: de la prévention à la territorialisation du risque," Revue Géographique de l'Est, vol. 53, no. 1-2, pp. 1-14, 2013.

[48] J. I. López-Moreno, S. M. Vicente-Serrano, E. Morán-Tejeda, J. Lorenzo-Lacruz, A. Kenawy, and M. Beniston, "Effects of the North Atlantic Oscillation (NAO) on combined temperature and precipitation winter modes in the Mediterranean mountains: observed relationships and projections for the 21st century," Global and Planetary Change, vol. 77, no. 1-2, pp. 6276, 2011. 

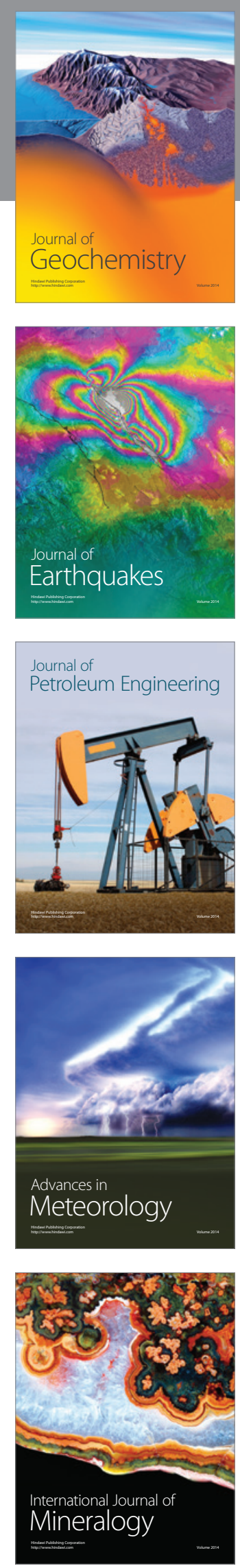
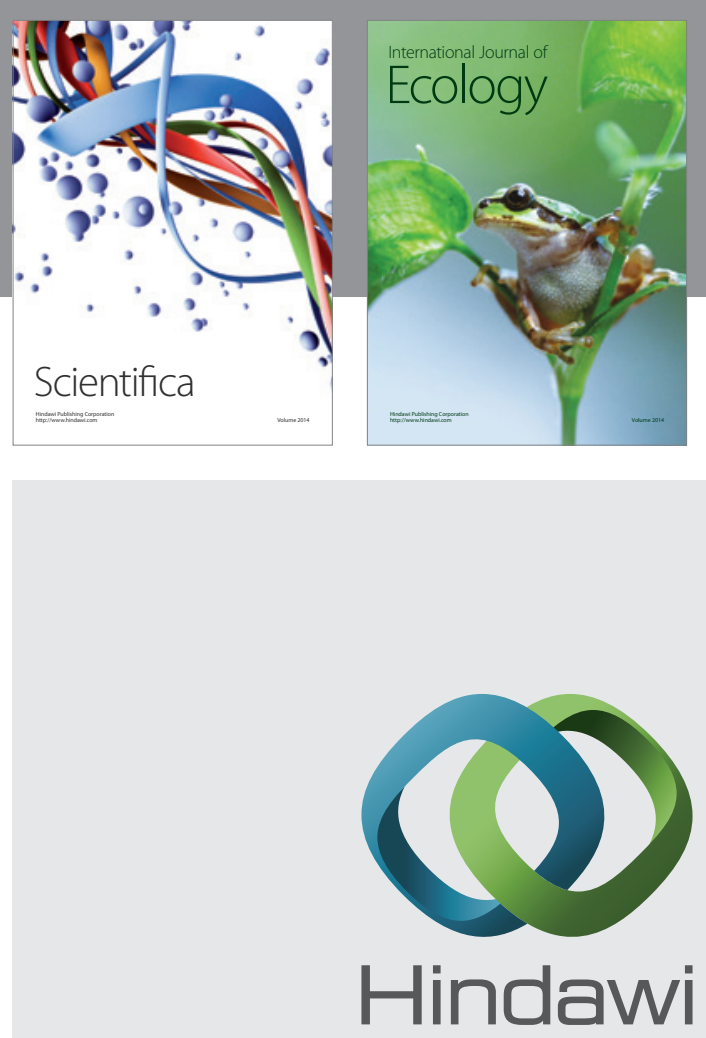

Submit your manuscripts at

http://www.hindawi.com
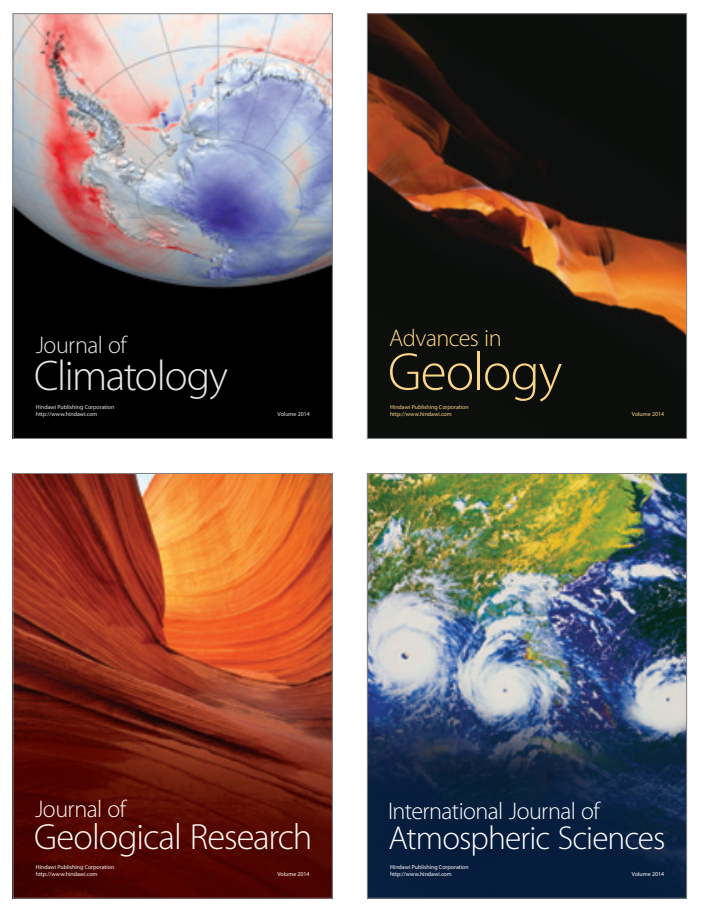

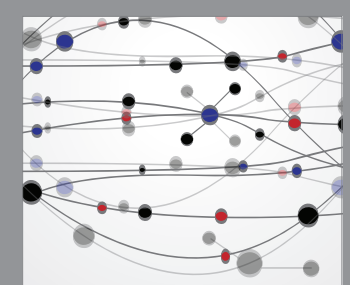

The Scientific

\section{World Journal}
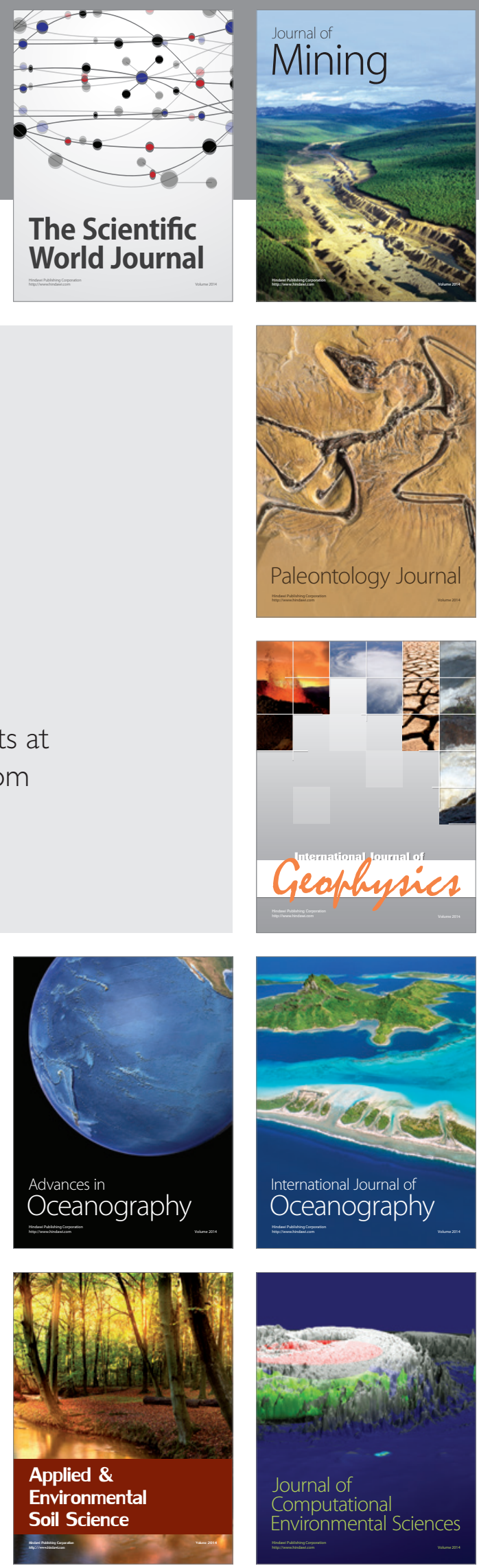